\title{
The Attitude of Santri and Ustadz Toward Multilingual Education at Pesantren
}

\author{
Saidna Zulfiqar Bin Tahir \\ English Education Department, University of Iqra Buru, Ambon, Indonesia
}

Email address:

saidnazulfiqar@gmail.com

To cite this article:

Saidna Zulfiqar Bin Tahir. The Attitude of Santri and Ustadz Toward Multilingual Education at Pesantren. International Journal of Language and Linguistics. Vol. 3, No. 4, 2015, pp. 210-216. doi: 10.11648/j.ij11.20150304.13

\begin{abstract}
The attitude is one of the important aspects of multilingual teaching and learning successful at Pesantren or Islamic boarding school in Indonesia. This study aimed to know the effect of attitude of Santri/students and Ustadz/teachers toward multilingual education at Pesantren in Makassar, Indonesia. This study applied quantitative approach using survey design. The population of the study is all Santri and Ustadz of Pesantren of IMMIM, Pondok Madinah, and Pesantren of Darul Arqam Muhammadiyah Gombara amount to 839 populations which consist of 788 Santries and 51 Ustadzs in academic year $20014 / 2015$. The total samples of simple random sampling technique are 85 then accomplished to 100 samples. In collecting data, the researcher employed questionnaire using Likert Scale model. The data have been analyzed descriptively and inferentially using SPSS Ver. 17.The researcher found that there was an effect of Santri and Ustadzs' attitude toward multilingual education at pesantren but it was not significant caused of the lack of knowledge, belief, and loyalty to the government regulation.
\end{abstract}

Keywords: Attitude, Santri, Ustadz, Multilingual Education, Pesantren

\section{Introduction}

Pesantren or Islamic boarding school is an educational institution that has its roots on the Hinduism-Islamic educational system which was founded by $\mathrm{Ki}$ Hajar Dewantara as the indigenous education system of Indonesia since 1062 (Yasmadi, 2002: 99; Daulay, H.P, 2009: 61; Madjid, 2013: 3; Nizar, at al., 2013: 85; Engku, at al., 2014: 107). The word 'Pesantren' derived from the word 'Santri' with preffix -pe and suffix -an means a place where a santri/student lives (Dhofier, 1984: 18; Daulay, 2009: 61; Nizar: 87; Engku, at al., 2014: 172).

According to Madjid (2013: 21), there are two conceptions of the word 'Santri' regarding to its origin. Firstly, the word 'Santri' derived from Sanskrit language 'Shastri'. It means literate or able to read and write. Therefore, Santri is a literary person because of his knowledge concerning to the Holy Scripture. Secondly, the word 'Santri' came from Javanese language 'cantrik' which means a person who go a long with a teacher wherever he goes and stays to acquire knowledge and skill from him or a person who pursues a course from a teacher. The pattern of relationship between teacher and Santri (guru-cantrik) used largely in the era of Islam so that it changed from 'guru-cantrik' to 'guru-santri'. Subsequently, the word 'guru' changed into 'Kiai' or 'Ustadz' which means old, sacred, and holy person.

An institution could be classified as pesantren when it complies with some conditions or some basic elements of pesantren, they are; Kiai/Ustadz/teacher, santri/students, mosque, pondok/dormitory, and religious teaching or teaching the Holy Scripture. Based on the views and explanation above, the researcher concludes that pesantren is an educational institution of religious teaching consists of Kiai/Ustadz, santri, mosque, and dormitory where all santri/students must stay inside of pesantren to learn the Holy Scripture and religious sciences (Dhofier, 1984: 44).

Nowadays, there are 27.218 pesantrens in Indonesia including 240 pesantrens in South Sulawesi/Makassar and the number of pesantrens will increase from day to day based on its graduate who intends to build the branch or the new one. This educational institution's learning system is modernized and developed by applying the combination of religious and general subjects, especially the subjects of two foreign languages - besides, Indonesian and local languages - those are, Arabic and English in teaching and learning process and also use them in daily communication inside of pesantren. The obligation to use the foreign languages was intended to improve the students' knowledge in Islamic study and science through their languages skill (Depag: Direktori Pondok 
Pesantren, 2011: 173).

This study will focus on modern pesantrens in City of Makassar which implemented two foreign languages such English and Arabic in teaching and learning process and also used them in daily communication; Pesantren of IMMIM, Pondok Madinah, and Pesantren of Darul Arqam Muhammadiyah Gombara. Those Pesantrens have been chosen as research location by the consideration that these schools have very interesting linguistic tradition. There are two intensive foreign languages have been taught and learned at the schools, namely Arabic and English. Besides, the students generally come from various tribes in the eastern of Indonesia with different ethnics and languages, namely Bugis, Makassar, Mandar, Palu, Kendari, Gorontalo, Kalimantan, Maluku, Papua and Java that made pesantren became multilingualism community.

Some previous studies involved to pesantren still focused on method of languages teaching and learning, some researchers studied about linguistics and sociolinguistic related to the speech style, bilingual, code-mixing and code-switching, and some others discussed on teaching morality, teaching Kitab Kuning, and religious learning. But those studies didn't consider in-depth yet on multilingual education that occurred at pesantren (Melor, et al, 2012: 87; Bin Tahir, S, 2011: 81; Hanidah, 2009; Rhohmatillah, 2013; Tantri, 2013: 37; (Lukens-Bull, 2000: 27; Van Bruinessen, 1994: 121; Zakaria, 2010: 45).

These reasons awaken the researcher's heart to conduct a study on multilingual education which appropriate to the characteristic of pesantren before conducting multilingual material development for pesantrens' students. This article only focuses and specifies on the exploration of the attitude of Santri and Ustadz toward multilingual education at pesantren

\subsection{Multilingual Education in Pesantren Context}

Most psycholinguistic researchers define multilingualism as the use of three or more languages, but this entails defining what a language is, which can be problematic. Some writers and researchers tried to define multilingual based on the definition of monolingual and bilingual, while the definitions were still confused. For instance, Bloomfield (1933: 56) defined bilingualism as "the native-like control of two languages" whereas it is so hard to be native-like caused of the fossilization of organ of speech in the early edge (12 years old) and it was so hard to master all skills of language, even a native cannot master them all (Zhaohong \& Odlin, 2004: 4). Consequently, the definition of bilingualism is still debated by the researchers and writers. Thus the discussion of definitions of multilingualism is therefore also complex.

In general, a multilingual is a person who has the ability to use three or more languages, either separately or in various degrees of code-mixing, in which different languages are used for different purposes, competence in each varying according to such factors as register, occupation, and education (McArthur, 1992: 673; Edwards, 1994: 33; Vildomec, 1963: 28; Kemp, 2009). Multilingual may not have equal proficiency in or control over all the languages they know.

Multilingualism is a considerable number of people speak more than two languages in their everyday life due to historical, social, or economic reasons (Cenoz, 2000: 53). They may live in a multilingual community as a result of colonialism and immigration, or they might be in constant contact with different monolingual communities because of globalization. Multilingual speakers use different languages for different contexts and purposes, and they are highly unlikely to have equivalent levels of proficiency in all the languages they possess (Kemp, 2009).

According to this perspective, the researcher concludes into the definition of multilingual individuals is that who can, to whatever degree, comprehend or produce spoken utterances or written in more than two languages. Thus, persons able to speak in a third language (e.g. Arabic) but unable to function in the written language are considered to be multilingual of a certain type and placed at one end of the continuum. On the contrary, persons can write in second or third language (e.g. English) but unable to function it in spoken language is also considered as multilingual person. Such persons are said to have receptive competence in a second and third language and to be 'more multilingual' than monolinguals that have neither receptive nor productive abilities in a language other than their first.

In many pesantrens in Indonesia learning a second and third language at school presents a common experience for many students. In the pesantren context this means that a number of students study and have been taught in two foreign languages at school, such as English and Arabic. But the first language and local language learning also takes place in schools, thus several languages are used as media of instruction.

\subsection{The Attitude Toward Multilingual Education}

Attitude is a feeling, belief, or opinion of approval or disapproval towards something. An attitude is a predisposition to respond cognitively, emotionally, or behaviorally to a particular object, person, or situation in a particular way. Attitudes have three main components: cognitive, affective, and behavioral. The cognitive component concerns one's beliefs; the affective component involves feelings and evaluations; and the behavioral component consists of ways of acting toward the attitude object. The cognitive aspects of attitude are generally measured by surveys, interviews, and other reporting methods, while the affective components are more easily assessed by monitoring physiological signs such as heart rate. Behavior, on the other hand, may be assessed by direct observation (Strickland, 2001: 56).

Multilingual education refers to the use of two or more languages as medium of instruction. The purpose of a multilingual education (MLE) program is to develop appropriate cognitive and reasoning skills through a program of structured language learning and cognitive development, enabling students to operate successfully in their native, state and national languages.

MLE provides a strong foundation in the first language 
(mother tongue), adding second (e.g. national) and third languages (e.g. English) enabling the appropriate use of both/all languages for life-long learning (Malone, 2005: 71). Multilingual education is also multicultural, with learning beginning in the students' known environment and bridging to the wider world. The bridging process allows them to maintain local language and culture while providing state and/or national language acquisition and instruction. This process provides learners with the opportunity to contribute to national society without forcing them to sacrifice their linguistic and cultural heritage.

Based on the views above, it could be simplified that the multilingual education aimed to develop appropriate cognitive and reasoning skills. On the other hand, the attitude has three main components: cognitive, affective, and behavioral. Thus the successful of multilingual education system depends on the attitude of students and teachers toward multilingual teaching and learning that will be discussed in this study.

\section{Method}

The study applied quantitative approach using survey design to gather data at a particular point in time with the intention of describing the nature of existing conditions, or identifying standards against which existing conditions can be compared, or determining the relationships that exist between specific events (Cohen, at a.1, 2007: 169; Creswell, 2008: 387).

The population of the study is all Santri and Ustadz of Pesantren of IMMIM, Pondok Madinah, and Pesantren Darul Arqam Muhammadiyah Gombara amount to 839 which consist of 788 santries and 51 Ustadzs. The total samples of simple random sampling technique are 85 then accomplished to 100 samples. In collecting data, the researcher employed questionnaire using Likert Scale model as can be seen in the appendix. The data have been analyzed descriptively and inferentially using SPSS Ver. 17.

\section{Finding and Discussion}

The analysis result of Santri and Ustadzs' attitude toward multilingual education at pesantren can be described on the table as follow:

Table 1. Statistic descriptive of Santri and Ustadzs' attitude.

\begin{tabular}{lllllll}
\hline Variabel & N & Minimum & Maximum & Sum & Mean & Std. Deviation \\
\hline Attitude & 100 & 21 & 50 & 3202 & 32.02 & 8.075 \\
\hline
\end{tabular}

Table 2. Frequency and Percentage of Santri and Ustadzs' Attitude.

\begin{tabular}{llll}
\hline Interval Score & Frequency & Percentage (\%) & Category \\
\hline $47-55$ & 4 & 4 & Most Positive \\
$38-46$ & 22 & 22 & Positive \\
$29-37$ & 30 & 30 & Neutral \\
$20-28$ & 44 & 44 & Negative \\
$11-19$ & 0 & 0 & Most Negative \\
Total & 100 & 100 & \\
\hline
\end{tabular}

The mean score of Santri and Ustadzs' attitude toward multilingual education at pesantren is 32.02 with the higher score is 50 and the lowest is 21 . The standard deviation is 8.075 interpreted as $68 \%$. It could be said that the attitude of Santri and Ustadz toward multilingual education is approximate (23.574 to 39.946 ) as could be described on the tabel 2 .

The table shows that the frequency of attitude score tending to have a positive effect as much as $24 \%$, in the contrary, $76 \%$ of Santri and Ustadzs inclined to negative effect as can be described on the figure below:

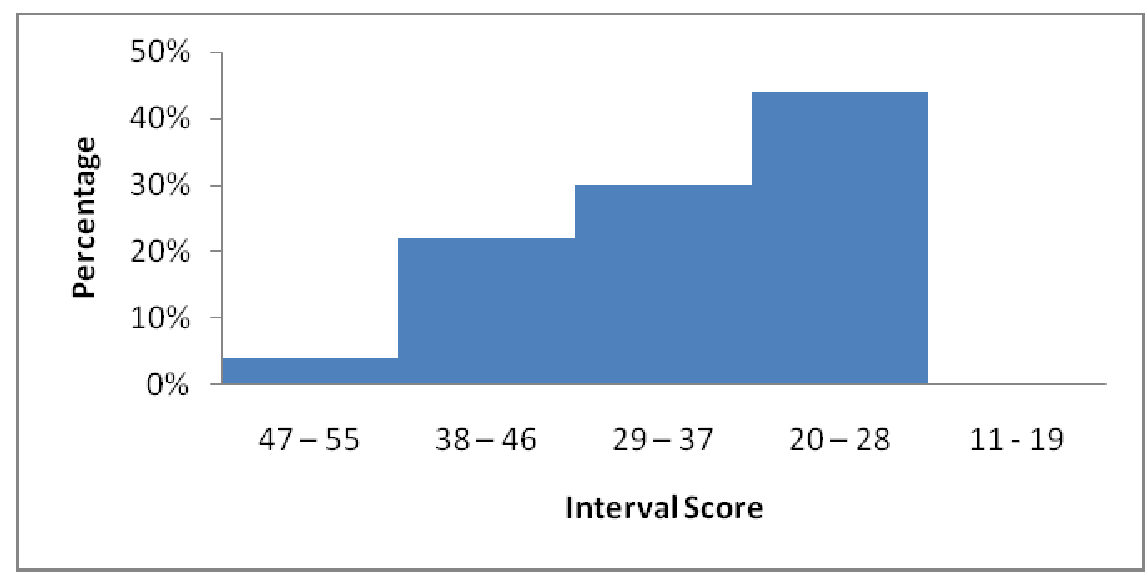

Figure 1. Percentage of Santri and Ustadzs' attitude toward multilingual education.

The figure shows that $44 \%$ of santri and ustadzs' attitude tend to have negative attitude, $30 \%$ in a neutral attitude, $22 \%$ have positive attitude, and $4 \%$ have most positive attitude. The result analysis shows that the probability value is $0.000<0.05$ which is used in this study. It means that the $\mathrm{H}_{0}$ was rejected or there is an effect of attitude toward multilingual education at Pesantren where the constant value is 1.281 , this shows if there is no increasing value of cognitive attitude so that the contribution of attitude in multilingual education is 1.281 , and the significant of regression value is 0.499 . It can be predicted 
that each of the increasing of one value of cognitive attitude

will give the increasing value on the attitude as much as 0.499 .

Table 3. Regression analysis result on Santri and Ustadzs'attitude.

\begin{tabular}{|c|c|c|c|c|c|c|}
\hline \multirow{2}{*}{\multicolumn{2}{|c|}{ Model }} & \multicolumn{2}{|c|}{ Unstandardized Coefficients } & \multirow{2}{*}{$\begin{array}{l}\text { Standardized Coefficients } \\
\text { Beta }\end{array}$} & \multirow{2}{*}{$\mathbf{t}$} & \multirow{2}{*}{ Sig. } \\
\hline & & B & Std. Error & & & \\
\hline \multirow{2}{*}{1} & (Constant) & 1.281 & .273 & & 4.698 & .000 \\
\hline & Attitude & .521 & .092 & .499 & 5.695 & .000 \\
\hline
\end{tabular}

The attitude of Santri and Ustadz toward multilingual education at pesantren with the contribution value of the attitude as much as $24.9 \%$ shows that it didn't give the significant contribution yet to improve the process of multilingual education at pesantren. The inclination of Santri and Ustadzs to be active in multilingual education was more important where the attitude pertain to the Santri and Ustadz awareness to behave. It is corresponding with Festinger's statement that one's attitude connected to his real behavior where the attitude covers three components, i.e. cognitive, affective and behavior. One's attitude occasionally is consistent to other components and also in his behavior which known as the cognitive dissonance theory (Walgito, 2010:136).

Based on this point of view, it could be stated that the low of knowledge on the benefit of multilingual education will bring the negative expectation to the surface which influence the attitude of Santri and Ustadzs. The low of knowledge, belief, the lack of chances and the government attention as an organization to endorse the program, and the complicated curriculum applied in pesantren as a basic for the Santri and Ustadzs to behave. As stated by Strickland (2001: 56).that the attitude will always connected to the cognitive, in which one will behave positively to an object if he/she has high cognitive index and vice versa. It is correspond to views of Walgito (2003: 135) and Sarwono, (2010: 205) who stated that the developing of one's attitude influenced by psychology, physiology, and character which force one will respond and perceive selectively to his outside world as a stimuli to behave or to change the behavior.

The Santri and Ustadz have capability to realize what has happened in the educational system of pesantren which always follow the rule regulated by the government. This regulation is only siding with the state school or government school and of course it injures educational system of pesantren. This reason made as consideration factor to organize multilingual education. Thus, the knowledge of Santri and Ustadzs as a cognitive component of attitude played an important role in forming the attitude. The cognitive aspect of attitude is resource of information which evaluated by affective component positively or negatively.

The characteristic of Santri and Ustadz of pesantren categorized as an obedience person toward the government regulation, so that the curriculum of pesantren could be licensed and accredited by the government. The lack of motivation to develop multilingual education system in teaching and learning process caused of the rule regulated by the government who act toward the curriculum and national examination and school accreditation system. Therefore, the way of Santri and Ustadzs thinking must be changed in order to motivate those to create vary of motive and ways in arranging multilingual education at pesantren that appropriate to the government curriculum. As stated by Newcomb (in Walgito, 2010), the perspective of cognitive attitude represent viewpoint of motivation, the attitude indicated the condition of readiness of enthusiasm.

\section{Conclusion}

Based on the explanation above, the researcher found that there was an effect of Santri and Ustadzs' attitude toward multilingual education at pesantren but it was not significant caused of the lack of knowledge, belief, and loyalty to the government regulation.

Pesantren must be responsive to manage his own curriculum of multilingual education. The role of the government as a policy maker must consider in-depth the educational system of pesantren as an element of educational system in Indonesia in order to supporting and empowering the human resource of the nation through multilingual education.

\section{Acknowledgements}

The research is financed by The Higher Education Directorate of Indonesia. Thanks to Prof. Haryanto and Dr. Syarifuddin Dolah in State University of Makassar.

\section{Appendix}

\section{Appendix 1: Questionnaire of Attitude toward Multilingual Education at Pesantren}

\section{Angket Sikap}

Terima kasih atas waktu dan kesediaan Bapak/Ibu/Santri untuk menjawab pernyataan-pernyataan yang tertulis di bawah ini. Informasi yang benar dari Bapak/Ibu/Santri sangat bermanfaat untuk mengetahui Analisis Sikap Santri dan Ustadz terhadap Pembelajaran Multilingual di Pesantren. Adapun informasi yang diberikan bukan untuk keperluan proyek melainkan dalam rangka penyelesaian studi akhir Program Pascasarjana Universitas Negeri Makassar. 
1. NAMA:

2. UMUR:

3. PEKERJAAN:

4. PESANTREN:

5. JENJANG/KLS:

6. ALAMAT:

B. SIKAP SANTRI DAN USTADZ TERHADAP MULTILINGUAL

Petunjuk: Pilihlah Salah satu jawaban yang paling sesuai menurut Anda dengan memberi tanda $(\sqrt{ })$ pada kolom jawaban yang telah disediakan. Jawablah pernyataan dibawah ini dengan mencentang opsi (SS) sangat setuju, (S) setuju, (RR) ragu-ragu, (TS) tidak setuju, dan (STS) sangat tidak setuju.

\begin{tabular}{|c|c|c|c|c|c|c|}
\hline No & PERNYATAAN & SS & $\mathbf{S}$ & RR & TS & STS \\
\hline 1 & $\begin{array}{l}\text { Pembelajaran Multilingual di Pesantren merupakan hal yang positif untuk meningkatkan kemampuan berbahasa } \\
\text { multilingual siswa dan guru. }\end{array}$ & & & & & \\
\hline 2 & $\begin{array}{l}\text { Aktivitas pembelajaran multilingual tanpa adanya aturan yang ketat dalam mengatur aktfifitas berhasa merupakan } \\
\text { hal negatif bagi perkembangan berbahasa multilingual siswa dan civitas Pesantren lainnya }\end{array}$ & & & & & \\
\hline 3 & $\begin{array}{l}\text { Pembelajaran multilingual memberikan manfaat positif bagi para santri untuk mengembangkan ilmu } \\
\text { pengetahuannya. }\end{array}$ & & & & & \\
\hline 4 & $\begin{array}{l}\text { Kemampuan berbahasa asing (Inggris, Arab) merupakan bagian dari kebanggan santri dan Pesantren yang harus } \\
\text { dipertahankan dan ditingkatkan. }\end{array}$ & & & & & \\
\hline 5 & $\begin{array}{l}\text { Berbahasa daerah atau berbahasa Indonesia mengangu keseriusan para santri meningkatkan kemampuan bahasa } \\
\text { asing. }\end{array}$ & & & & & \\
\hline 6 & Para santri dan guru diberikan kebebasan untuk berbahasa daerah atau Indonesia di lingkungan Pesantren. & & & & & \\
\hline 7 & Aktifitas berbahasa di lingkungan Pesantren perlu dimonitoring, baik oleh guru maupun para santri itu sendiri. & & & & & \\
\hline 8 & $\begin{array}{l}\text { Santri, guru dan pengurus Pesantren memiliki tanggungjawab dalam menjaga keberlanjutan pembelajaran } \\
\text { multilingual di Pesantren. }\end{array}$ & & & & & \\
\hline 9 & Lingkungan Pesantren sangat tepat untuk dijadikan model pembelajaran multilingual. & & & & & \\
\hline 10 & Pembelajaran multilingual merupakan kegiatan yang merugikan para santri. & & & & & \\
\hline 11 & Perlunya keterlibatan santri dalam perencanaan dan pengelolaan pembelajaran multilingual. & & & & & \\
\hline
\end{tabular}

Appendix 2: The Data of 100 Respondents'Attitude toward Multilingual Education

Source: research data on Santri and Ustadzs' attitude toward multilingual education at pesantren, 2015

\begin{tabular}{|c|c|c|c|c|c|c|c|c|c|c|c|c|c|c|}
\hline \multirow{2}{*}{ No } & \multirow{2}{*}{$\begin{array}{l}\text { Respondents } \\
\text { (Initial) }\end{array}$} & \multicolumn{12}{|c|}{ item of questionnaire } & \multirow{2}{*}{ Mean score } \\
\hline & & 1 & 2 & 3 & 4 & 5 & 6 & 7 & 8 & 9 & 10 & 11 & total & \\
\hline 1 & IL & 4 & 5 & 4 & 4 & 4 & 5 & 4 & 4 & 4 & 4 & 3 & 45 & 4,09 \\
\hline 2 & $\mathrm{JL}$ & 4 & 5 & 4 & 4 & 4 & 5 & 4 & 4 & 5 & 4 & 3 & 46 & 4,18 \\
\hline 3 & SL & 4 & 3 & 3 & 3 & 4 & 4 & 4 & 3 & 4 & 3 & 2 & 37 & 3,36 \\
\hline 4 & $\mathrm{KD}$ & 4 & 3 & 4 & 3 & 4 & 3 & 4 & 4 & 4 & 3 & 2 & 38 & 3,45 \\
\hline 5 & AAZ & 5 & 3 & 4 & 2 & 3 & 2 & 1 & 3 & 1 & 3 & 4 & 31 & 2,82 \\
\hline 6 & HW & 5 & 4 & 3 & 2 & 3 & 1 & 3 & 1 & 2 & 4 & 2 & 30 & 2,73 \\
\hline 7 & SSL & 4 & 4 & 3 & 3 & 3 & 2 & 2 & 2 & 3 & 4 & 2 & 32 & 2,91 \\
\hline 8 & MMK & 2 & 1 & 2 & 3 & 2 & 3 & 1 & 3 & 1 & 2 & 2 & 22 & 2,00 \\
\hline 9 & LOI & 2 & 1 & 2 & 3 & 2 & 3 & 1 & 3 & 1 & 2 & 3 & 23 & 2,09 \\
\hline 10 & HR & 4 & 1 & 1 & 3 & 2 & 2 & 1 & 2 & 1 & 4 & 3 & 24 & 2,18 \\
\hline 11 & ZI & 4 & 1 & 1 & 2 & 2 & 2 & 1 & 2 & 1 & 3 & 2 & 21 & 1,91 \\
\hline 12 & AR & 5 & 3 & 4 & 2 & 4 & 2 & 2 & 1 & 2 & 3 & 3 & 31 & 2,82 \\
\hline 13 & NS & 5 & 3 & 4 & 2 & 3 & 1 & 2 & 3 & 2 & 4 & 3 & 32 & 2,91 \\
\hline 14 & JA & 4 & 4 & 2 & 3 & 3 & 2 & 3 & 4 & 4 & 4 & 3 & 36 & 3,27 \\
\hline 15 & AWT & 4 & 4 & 3 & 3 & 3 & 2 & 2 & 4 & 4 & 4 & 2 & 35 & 3,18 \\
\hline 16 & $\mathrm{BM}$ & 4 & 4 & 3 & 2 & 3 & 3 & 2 & 3 & 1 & 4 & 2 & 31 & 2,82 \\
\hline 17 & MLS & 4 & 4 & 3 & 4 & 3 & 3 & 2 & 3 & 3 & 4 & 2 & 35 & 3,18 \\
\hline 18 & HLE & 3 & 2 & 3 & 3 & 3 & 3 & 2 & 3 & 2 & 4 & 3 & 31 & 2,82 \\
\hline 19 & SP & 3 & 2 & 2 & 3 & 2 & 3 & 2 & 3 & 2 & 3 & 3 & 28 & 2,55 \\
\hline 20 & RMA & 2 & 2 & 2 & 1 & 2 & 2 & 1 & 2 & 2 & 3 & 3 & 22 & 2,00 \\
\hline 21 & RS & 2 & 2 & 2 & 1 & 2 & 2 & 2 & 2 & 4 & 3 & 4 & 26 & 2,36 \\
\hline 22 & AR & 2 & 2 & 2 & 1 & 2 & 3 & 2 & 2 & 3 & 2 & 1 & 22 & 2,00 \\
\hline 23 & $\mathrm{HH}$ & 2 & 2 & 2 & 4 & 3 & 3 & 3 & 2 & 3 & 2 & 3 & 29 & 2,64 \\
\hline 24 & LR & 4 & 3 & 1 & 2 & 1 & 2 & 1 & 2 & 1 & 2 & 2 & 21 & 1,91 \\
\hline 25 & LDJ & 3 & 3 & 1 & 2 & 1 & 2 & 3 & 2 & 1 & 2 & 1 & 21 & 1,91 \\
\hline 26 & $\mathrm{AA}$ & 3 & 3 & 2 & 4 & 3 & 3 & 2 & 3 & 2 & 2 & 2 & 29 & 2,64 \\
\hline 27 & IS & 3 & 4 & 4 & 4 & 5 & 4 & 4 & 3 & 4 & 2 & 4 & 41 & 3,73 \\
\hline 28 & HH & 3 & 4 & 2 & 2 & 3 & 2 & 3 & 2 & 4 & 3 & 2 & 30 & 2,73 \\
\hline 29 & DM & 4 & 4 & 4 & 5 & 5 & 4 & 5 & 4 & 4 & 2 & 4 & 45 & 4,09 \\
\hline 30 & $\mathrm{HP}$ & 4 & 4 & 4 & 4 & 5 & 5 & 4 & 4 & 4 & 2 & 4 & 44 & 4,00 \\
\hline 31 & IR & 4 & 4 & 3 & 2 & 3 & 3 & 2 & 2 & 2 & 2 & 1 & 28 & 2,55 \\
\hline
\end{tabular}




\begin{tabular}{|c|c|c|c|c|c|c|c|c|c|c|c|c|c|c|}
\hline \multirow{2}{*}{ No } & \multirow{2}{*}{$\begin{array}{l}\text { Respondents } \\
\text { (Initial) }\end{array}$} & \multicolumn{12}{|c|}{ item of questionnaire } & \multirow{2}{*}{ Mean score } \\
\hline & & 1 & 2 & 3 & 4 & 5 & 6 & 7 & 8 & 9 & 10 & 11 & total & \\
\hline 32 & RRA & 4 & 4 & 3 & 2 & 3 & 3 & 2 & 4 & 4 & 2 & 3 & 34 & 3,09 \\
\hline 33 & RRB & 4 & 4 & 2 & 2 & 3 & 3 & 2 & 2 & 4 & 3 & 2 & 31 & 2,82 \\
\hline 34 & SI & 4 & 4 & 3 & 2 & 3 & 3 & 2 & 2 & 2 & 3 & 1 & 29 & 2,64 \\
\hline 35 & $\mathrm{IM}$ & 4 & 4 & 4 & 3 & 4 & 5 & 4 & 4 & 5 & 2 & 4 & 43 & 3,91 \\
\hline 36 & DS & 5 & 3 & 2 & 3 & 2 & 3 & 3 & 4 & 5 & 2 & 5 & 37 & 3,36 \\
\hline 37 & SDJ & 5 & 3 & 2 & 3 & 1 & 2 & 3 & 1 & 3 & 3 & 4 & 30 & 2,73 \\
\hline 38 & NA & 5 & 3 & 2 & 3 & 2 & 2 & 1 & 3 & 1 & 2 & 1 & 25 & 2,27 \\
\hline 39 & HS & 4 & 4 & 3 & 3 & 3 & 4 & 4 & 4 & 4 & 3 & 2 & 38 & 3,45 \\
\hline 40 & LP & 4 & 3 & 3 & 3 & 4 & 3 & 3 & 4 & 4 & 3 & 4 & 38 & 3,45 \\
\hline 41 & E & 4 & 5 & 4 & 4 & 4 & 5 & 3 & 4 & 5 & 3 & 3 & 44 & 4,00 \\
\hline 42 & $\mathrm{NN}$ & 4 & 5 & 4 & 4 & 3 & 2 & 4 & 4 & 5 & 3 & 3 & 41 & 3,73 \\
\hline 43 & $\mathrm{AF}$ & 2 & 2 & 2 & 4 & 3 & 3 & 3 & 3 & 3 & 2 & 3 & 30 & 2,73 \\
\hline 44 & $\mathrm{JT}$ & 2 & 2 & 2 & 4 & 3 & 3 & 2 & 3 & 3 & 2 & 3 & 29 & 2,64 \\
\hline 45 & MDJ & 3 & 3 & 2 & 2 & 1 & 2 & 3 & 1 & 1 & 2 & 1 & 21 & 1,91 \\
\hline 46 & HD & 3 & 3 & 2 & 4 & 3 & 2 & 3 & 1 & 1 & 3 & 2 & 27 & 2,45 \\
\hline 47 & AS & 3 & 3 & 2 & 4 & 3 & 2 & 2 & 3 & 2 & 2 & 3 & 29 & 2,64 \\
\hline 48 & MS & 3 & 3 & 3 & 4 & 3 & 2 & 3 & 3 & 2 & 2 & 3 & 31 & 2,82 \\
\hline 49 & SK & 3 & 3 & 3 & 4 & 3 & 2 & 2 & 3 & 2 & 4 & 3 & 32 & 2,91 \\
\hline 50 & PK & 4 & 5 & 4 & 4 & 5 & 4 & 5 & 5 & 5 & 3 & 3 & 47 & 4,27 \\
\hline 51 & RS & 4 & 5 & 4 & 4 & 5 & 4 & 5 & 4 & 4 & 4 & 3 & 46 & 4,18 \\
\hline 52 & AK & 4 & 4 & 1 & 2 & 3 & 3 & 3 & 4 & 4 & 4 & 5 & 37 & 3,36 \\
\hline 53 & SDF & 4 & 4 & 4 & 5 & 5 & 5 & 5 & 5 & 4 & 4 & 5 & 50 & 4,55 \\
\hline 54 & BL & 5 & 4 & 4 & 4 & 5 & 5 & 4 & 4 & 4 & 4 & 4 & 47 & 4,27 \\
\hline 55 & IR & 3 & 1 & 2 & 3 & 2 & 1 & 2 & 3 & 3 & 3 & 3 & 26 & 2,36 \\
\hline 56 & AMH & 3 & 1 & 2 & 3 & 2 & 2 & 2 & 2 & 2 & 3 & 3 & 25 & 2,27 \\
\hline 57 & MLA & 2 & 3 & 2 & 2 & 3 & 2 & 3 & 3 & 3 & 2 & 2 & 27 & 2,45 \\
\hline 58 & RS & 4 & 4 & 4 & 4 & 5 & 5 & 5 & 4 & 3 & 3 & 4 & 45 & 4,09 \\
\hline 59 & SL & 4 & 4 & 3 & 4 & 5 & 4 & 4 & 5 & 4 & 4 & 5 & 46 & 4,18 \\
\hline 60 & HL & 4 & 4 & 5 & 4 & 4 & 4 & 5 & 4 & 4 & 4 & 5 & 47 & 4,27 \\
\hline 61 & NA & 3 & 5 & 5 & 4 & 4 & 4 & 5 & 4 & 4 & 4 & 3 & 45 & 4,09 \\
\hline 62 & IL & 3 & 4 & 1 & 3 & 2 & 2 & 2 & 3 & 2 & 2 & 3 & 27 & 2,45 \\
\hline 63 & BHW & 3 & 4 & 1 & 3 & 2 & 2 & 3 & 3 & 2 & 2 & 2 & 27 & 2,45 \\
\hline 64 & MI & 3 & 4 & 1 & 3 & 2 & 1 & 2 & 3 & 3 & 2 & 2 & 26 & 2,36 \\
\hline 65 & JJ & 3 & 1 & 1 & 3 & 2 & 1 & 2 & 3 & 3 & 3 & 2 & 24 & 2,18 \\
\hline 66 & LMM & 5 & 4 & 3 & 2 & 3 & 3 & 2 & 3 & 3 & 2 & 3 & 33 & 3,00 \\
\hline 67 & FRS & 5 & 4 & 3 & 2 & 3 & 4 & 3 & 4 & 3 & 3 & 3 & 37 & 3,36 \\
\hline 68 & MSD & 3 & 1 & 2 & 3 & 4 & 3 & 3 & 4 & 2 & 3 & 2 & 30 & 2,73 \\
\hline 69 & AI & 2 & 2 & 2 & 3 & 2 & 2 & 3 & 3 & 2 & 3 & 2 & 26 & 2,36 \\
\hline 70 & $\mathrm{AF}$ & 2 & 2 & 2 & 3 & 2 & 2 & 3 & 1 & 2 & 2 & 3 & 24 & 2,18 \\
\hline 71 & B & 2 & 2 & 2 & 3 & 2 & 2 & 3 & 1 & 4 & 2 & 3 & 26 & 2,36 \\
\hline 72 & LLA & 2 & 2 & 3 & 2 & 2 & 2 & 3 & 1 & 2 & 2 & 3 & 24 & 2,18 \\
\hline 73 & NID & 3 & 2 & 2 & 2 & 3 & 2 & 2 & 2 & 2 & 2 & 1 & 23 & 2,09 \\
\hline 74 & LOS & 2 & 5 & 3 & 4 & 3 & 4 & 5 & 4 & 2 & 4 & 4 & 40 & 3,64 \\
\hline 75 & BM & 3 & 3 & 3 & 2 & 2 & 2 & 1 & 2 & 4 & 4 & 2 & 28 & 2,55 \\
\hline 76 & D & 3 & 3 & 3 & 2 & 2 & 1 & 1 & 2 & 3 & 4 & 2 & 26 & 2,36 \\
\hline 77 & $\mathrm{AD}$ & 2 & 2 & 2 & 2 & 2 & 3 & 1 & 3 & 3 & 4 & 3 & 27 & 2,45 \\
\hline 78 & $\mathrm{~J}$ & 2 & 2 & 2 & 2 & 2 & 3 & 3 & 3 & 3 & 2 & 2 & 26 & 2,36 \\
\hline 79 & NM & 2 & 2 & 2 & 2 & 2 & 1 & 3 & 3 & 3 & 2 & 2 & 24 & 2,18 \\
\hline 80 & PM & 4 & 2 & 2 & 2 & 3 & 3 & 3 & 3 & 2 & 2 & 2 & 28 & 2,55 \\
\hline 81 & IS & 3 & 2 & 2 & 2 & 3 & 2 & 3 & 2 & 2 & 3 & 4 & 28 & 2,55 \\
\hline 82 & RH & 3 & 2 & 2 & 2 & 3 & 2 & 3 & 2 & 2 & 2 & 4 & 27 & 2,45 \\
\hline 83 & LJ & 3 & 2 & 2 & 2 & 3 & 2 & 3 & 2 & 2 & 2 & 1 & 24 & 2,18 \\
\hline 84 & SDJ & 2 & 2 & 3 & 2 & 2 & 2 & 1 & 1 & 2 & 4 & 2 & 23 & 2,09 \\
\hline 85 & SA & 3 & 2 & 3 & 2 & 2 & 2 & 1 & 1 & 2 & 4 & 2 & 24 & 2,18 \\
\hline 86 & RRA & 2 & 4 & 3 & 4 & 3 & 5 & 4 & 4 & 5 & 3 & 4 & 41 & 3,73 \\
\hline 87 & RML & 2 & 4 & 3 & 3 & 3 & 4 & 4 & 4 & 4 & 3 & 4 & 38 & 3,45 \\
\hline 88 & LDS & 2 & 4 & 3 & 3 & 4 & 4 & 4 & 4 & 3 & 3 & 3 & 37 & 3,36 \\
\hline 89 & $\mathrm{IM}$ & 4 & 4 & 4 & 3 & 4 & 4 & 4 & 5 & 5 & 4 & 5 & 46 & 4,18 \\
\hline 90 & SIK & 2 & 2 & 2 & 1 & 2 & 3 & 3 & 3 & 2 & 3 & 3 & 26 & 2,36 \\
\hline 91 & ILM & 4 & 3 & 2 & 2 & 2 & 2 & 3 & 3 & 2 & 3 & 2 & 28 & 2,55 \\
\hline 92 & SDH & 5 & 4 & 4 & 3 & 4 & 5 & 4 & 5 & 4 & 4 & 4 & 46 & 4,18 \\
\hline 93 & LO & 2 & 2 & 2 & 1 & 3 & 3 & 4 & 5 & 4 & 2 & 2 & 30 & 2,73 \\
\hline 94 & UD & 2 & 2 & 2 & 2 & 3 & 2 & 3 & 4 & 2 & 2 & 2 & 26 & 2,36 \\
\hline 95 & HL & 2 & 2 & 2 & 1 & 2 & 2 & 3 & 3 & 2 & 2 & 2 & 23 & 2,09 \\
\hline 96 & KAS & 2 & 2 & 2 & 1 & 2 & 2 & 3 & 3 & 2 & 3 & 2 & 24 & 2,18 \\
\hline 97 & SM & 4 & 4 & 4 & 3 & 4 & 4 & 4 & 5 & 4 & 4 & 4 & 44 & 4,00 \\
\hline
\end{tabular}




\begin{tabular}{|c|c|c|c|c|c|c|c|c|c|c|c|c|c|c|}
\hline \multirow{2}{*}{ No } & \multirow{2}{*}{$\begin{array}{l}\text { Respondents } \\
\text { (Initial) }\end{array}$} & \multicolumn{12}{|c|}{ item of questionnaire } & \multirow{2}{*}{ Mean score } \\
\hline & & 1 & 2 & 3 & 4 & 5 & 6 & 7 & 8 & 9 & 10 & 11 & total & \\
\hline 98 & RIB & 4 & 4 & 4 & 3 & 4 & 5 & 5 & 5 & 4 & 4 & 4 & 46 & 4,18 \\
\hline 99 & SSL & 4 & 3 & 1 & 2 & 2 & 2 & 3 & 2 & 2 & 2 & 2 & 25 & 2,27 \\
\hline 100 & SM & 4 & 3 & 1 & 2 & 2 & 3 & 3 & 2 & 3 & 2 & 2 & 27 & 2,45 \\
\hline & & 333 & 307 & 263 & 279 & 293 & 283 & 285 & 301 & 289 & 290 & 279 & 3202 & \\
\hline
\end{tabular}

\section{References}

[1] Bin Tahir, S. Z. 2011. The Effectiveness of English Teaching Method at Pesantren IMMIM of Makassar. JUPITER Journal UPT Lib of University of Hasanuddin. Vol IX No. 1. November tahun 2011. No. ISSN: 1693-5535. p. 81-85.

[2] Bloomfield, L. 1933. Language. New York NY: Holt, Rinehart and Winston.

[3] Cenoz, J. 2000. Research on multilingual acquisition. In English in Europe: The Acquisition of a Third Language, J. Cenoz \& U. Jessner (eds), 39-53. Clevedon: Multilingual Matters.

[4] Cohen, L, Lawrence Manion and Keith Morrison. 2007. Research Methods in Education. Sixth edition. New York: Routledge.

[5] Creswell, W. John. 2008. Educational Research: Planning, conducting, and evaluating Quantitative and Qualitative Research. Third Edition. New Jersey: Pearson Prentice Hall.

[6] Daulay, H, Putra. 2009. Sejarah Pertumbuhan dan Pembaruan Pendidikan Islam di Indonesia. Jakarta: Kencana Prenada Media Group.

[7] Depag: Direktori Pondok Pesantren, 2011. Data statistik jumlah Pondok Pesantren di seluruh Indonesia. (Online) Accesed on March, 11, 2014 from http://pendis.kemenag.go.id/file/dokumen/.

[8] Dhofier, Zamakhsyari. 1982. Tradisi pesantren: Studi tentang pandangan hidup kyai. Jakarta: LP3ES.

[9] Engku, I \& Zubaidah, S. 2014. Sejarah Pendidikan Islami. Bandung; PT Remaja Rosdakarya.

[10] Hanidah, S. 2009. The Speech Styles Used By Multilingual Speakers in Pesantren Putri Al-Mawaddah Ponorogo. (Online) Accesed on December, 12, 2014 from http://lib.uin-malang.ac.id/?mod=th_detail\&id=05320108.

[11] Kemp, C. 2009. Defining multilingualism. In L. Aronin \& B. Hufeisen (Eds.), The exploration of multilingualism. Amsterdam, The Netherlands: John Benjamins. (pp. 11-26).

[12] Madjid, N. 2013. Bilik-Bilik Pesantren; Sebuah Potret Perjalanan. Jakarta: Penerbit Dian Rakyat.

[13] Lukens-Bull. 2000. Teaching Morality: Javanese Islamic Education in a Globalizing Era. Journal of Arabic and Islamic Studies. Vol. 3 (2000).
[14] Malone, S. 2005. Education for Multilingualism and Multi-literacy in Ethnic Minority Communities: the situation in Asia. In First Language First: Community-based literacy programmes for minority language context in Asia. Bangkok: UNESCO, pp.71-86.

[15] Melor, Yunus \& Hadi Salehi. 2012. The Effectiveness of Facebook Groups on Teaching and Improving Writing: Students' Perceptions. International Journal of Education and Information Technologies, Issue 1, Volume 6, 2012. Pp. 87-96.

[16] Nizar, S. 2013. Sejarah Sosial dan Dinamika Intelektual Pendidikan Islam di Nusantara. Jakarta: Kencana Prenada Media Group.

[17] Rhohmatillah. 2013. The use of code mixing used by male and female students of Ar-Raudlatul Hasanah Islamic Boarding School Medan. (Online) Access on December, 12, 2014 from http://digilib.unimed.ac.id/public/UNIMED-29258-811611101 $7 \% 20$.

[18] Sarwono W. Sarlito, 2010, Teori-teori Psikologi Sosial. Jakarta Raja Grafindo Persada.

[19] Strickland, B. (ed.). 2001. Gale encyclopedia of psychology. Second edition. Farmington Hills: Gale Group. p. 56.

[20] Tantri. 2013. English as a Global Language Phenomenon and the Need of Cultural Conceptualizations Awareness in Indonesian ELT. International Refereed \& Indexed Journal of English Language \& Translation Studies. ISSN: 2308-5460 April-June, 2013, pp 37-49.

[21] Van Bruinessen. 1994. Pesantren and Kitab Kuning: Continuity and Change in a Tradition of Religious Learning', in: Wolfgang Marschall (ed.), Texts from the islands: Oral and written traditions of Indonesia and the Malay world [Ethnologica Bernensia, 4], Berne: The University of Berne Institute of Ethnology, 1994, pp. 121-146.

[22] Walgito. B, 2003., Psikologi Sosial Suatu Pengantar. Yokyakarta: Andi

[23] Yasmadi. 2002. Modernisasi Pesantren. Jakarta: Ciputat Press.

[24] Zakaria. 2010. Pondok Pesantren: Changes and Its Future. Journal of Islamic and Arabic Education, 2.(2). 2010. 45-52.

[25] Zhaohong, H, and Odlin (Eds.). 2004. Studies of Fossilization in Second Language Acquisition. Clevedon: Multilingual Matters Ltd and MPG Books Ltd.

[26] Zhaohong, H, and Odlin (Eds.). 2004. Studies of Fossilization in Second Language Acquisition. Clevedon: Multilingual Matters Ltd and MPG Books Ltd. 